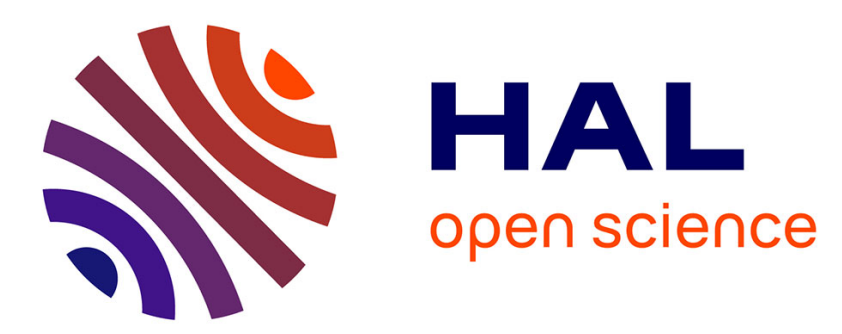

\title{
Understanding Nickel Responses in Plants: More Than Just an Interaction with Iron Homeostasis
}

Sylvain Merlot

\section{To cite this version:}

Sylvain Merlot. Understanding Nickel Responses in Plants: More Than Just an Interaction with Iron Homeostasis. Plant and Cell Physiology, 2020, 61 (3), pp.443-444. 10.1093/pcp/pcaa016 . hal02502308

\section{HAL Id: hal-02502308 \\ https://hal.science/hal-02502308}

Submitted on 20 Nov 2020

HAL is a multi-disciplinary open access archive for the deposit and dissemination of scientific research documents, whether they are published or not. The documents may come from teaching and research institutions in France or abroad, or from public or private research centers.
L'archive ouverte pluridisciplinaire $\mathbf{H A L}$, est destinée au dépôt et à la diffusion de documents scientifiques de niveau recherche, publiés ou non, émanant des établissements d'enseignement et de recherche français ou étrangers, des laboratoires publics ou privés. 


\section{Commentary}

\section{Understand nickel responses in plants: Not simply an interaction with iron homeostasis}

\section{Sylvain MERLOT}

Université Paris-Saclay, CEA, CNRS, Institute for Integrative Biology of the Cell (I2BC), 91198, Gif-sur-Yvette, France.

We have often belittled the role of nickel in plant biology, classifying this metal as a toxic element. However, nickel is the essential cofactor of the plant urease, which required to degrade urea into carbon dioxide and ammonia. Nickel therefore plays an important role in plants to limit the toxic accumulation of urea and recycle nitrogen. The question is whether plants have evolved specific pathways to regulate nickel homeostasis? Traces of nickel found in soils are usually sufficient to sustain urease activity in most of the plant species. As a consequence, the response to nickel deficiency has been little investigated so far. In contrast, toxic amounts of nickel are found in anthropogenically contaminated soils and in natural soils originating from ultramafic rocks including serpentine. These ultramafic soils have selected a very specific flora highly tolerant to high concentration of nickel present in the soil or accumulated in their cells (Kazakou et al., 2008). It is now important to understand the fundamental mechanisms involved in nickel tolerance in plants. Nickel excess provokes several physiological and macroscopic responses including chlorosis, necrosis, the limitation of plant development and the reduction of root growth. These effects are commonly proposed to be general consequences of an increased oxidative stress and competition with essential micro-elements including iron (Seregin and Kozhevnikova, 2006). Previously, Lešková et al. (2017) systematically investigated the effect of the excess of several metals including nickel, zinc and cadmium, on diverse physiological responses associated with iron deficiency. A kind of study of which everybody wants to know the results but that no-one dares to perform. This study revealed that nickel excess induces physiological and transcriptomic responses that are clearly distinct from a simple iron deficiency response. In contrast, the transcriptomic response to toxic excess of other elements, e.g. zinc, was found more similar to iron deficiency in this study.

In this issue, Lešková et al. (2019) further investigated the response of Arabidopsis thaliana plantlets to high nickel at transcriptomic, developmental and cellular levels. First, using $A$. thaliana gene expression microarrays, they identified 235 genes which expression changes significantly more than 2-fold in response to $100 \mu \mathrm{M} \mathrm{Ni}$ for 4 days. 56 of these differentially expressed (DE) genes are known to respond to iron starvation, thus confirming that nickel excess triggers an iron deficiency response. However, the remaining $75 \%$ of DE genes are not known to respond to iron deficiency. Among these genes, the most represented Gene 
Ontology categories correspond the regulation of hydrogen peroxide $\left(\mathrm{H}_{2} \mathrm{O}_{2}\right)$ metabolism, the transport and response to nitrate, and to genes potentially involved in the structure of the plantcell wall. The regulation of genes involved in nitrate homeostasis is worth further investigation because it could indicate a retro-control via nickel and urease activity on nitrogen metabolism. High nickel concentrations are known to inhibit the growth of Arabidopsis primary roots (Schaaf et al., 2006). Here, the authors analyzed more precisely the effect of nickel on root development. Using an elegant split agar plate assay, they show that nickel acts locally to inhibit primary root growth. They also observed that the excess of nickel increases secondary root emergence and induces gravitropic defect. To understand the effect of nickel on primary root growth, they examined pWOX5::GFP and pCYCB1;1::GUS markers but did not observe a major effect of nickel on the quiescent center nor on mitotic activity in the meristem. In contrast, they observed that high nickel limits longitudinal root cell expansion, while promoting radial expansion in the elongation zone. Because of these phenotypes, they investigated auxin distribution in response to high nickel using the $p D R 5::$ Venus marker. The conclusion of this analysis is that nickel excess mainly affects the shootward flux of auxin. Accordingly, nickel induced a rapid reduction of the PIN2 protein. The regulation of PIN2 level by nickel is more likely post-transcriptional and involves a change in PIN2 membrane trafficking. In contrast, other PIN auxin transporters, e.g. PIN1, are less affected by nickel, suggesting that PIN2 is a more specific target of the nickel response. It is still difficult to assemble all the parts of the nickel response puzzle described in this study. Yet, the increase of Reactive Oxygen Species (ROS) observed in roots in response to nickel may constitute a link between auxin signaling and the reduction of root elongation. The increase of ROS corroborates the increased expression of genes involved in $\mathrm{H}_{2} \mathrm{O}_{2}$ metabolism observed in the transcriptomic analysis. $\mathrm{H}_{2} \mathrm{O}_{2}$ was recently shown to affect the recycling of PIN2 in roots (Zwiewka et al., 2019). Interestingly, the treatment of roots with the superoxide dismutase inhibitor DDC restore the presence of PIN2 and partially restore the growth of roots in response to high nickel.

This study provides important new information on the response of plants to the excess of nickel. It remains to be established whether the responses observed in this study are specific to nickel or if other metal can trigger the same cellular responses in roots including the localized increase of ROS, the degradation of PIN2 or the re-orientation of the microtubule network. It would be also interesting to investigate if nickel specifically targets PIN2 or if it affects trafficking of other membrane protein, including ion transporters. Studies in yeast have shown that several genes involved in membrane trafficking are involved in nickel tolerance (Ruotolo et al., 2008).

Work on nickel responses in plants is importance for modern agriculture because we can project that nickel concentration in farming soils will regularly increase, especially in peri-urban area because of anthropogenic pollution. Urea is also widely used as a nitrogen fertilizer for 
crops. Most of the urea is metabolized in soils by microorganisms, but part of it is uptaken and metabolized by plants. Therefore, a better understanding of nickel responses and homeostasis in plants is important for modern agriculture to sustain food production and security.

\section{References}

Kazakou, E., Dimitrakopoulos, P.G., Baker, A.J.M., Reeves, R.D., and Troumbis, A.Y. (2008) Hypotheses, mechanisms and trade-offs of tolerance and adaptation to serpentine soils: from species to ecosystem level. Biol Rev. 83: 495-508.

Lešková, A., Giehl, R.F.H., Hartmann, A., Fargašová, A., and von Wirén, N. (2017) Heavy Metals Induce Iron Deficiency Responses at Different Hierarchic and Regulatory Levels. Plant Physiol. 174: 1648-1668.

Lešková, A., Zvarík, M., Araya, T., and Giehl, R.F.H. (2019) Nickel Toxicity Targets Cell WallRelated Processes and PIN2-Mediated Auxin Transport to Inhibit Root Elongation and Gravitropic Responses in Arabidopsis. Plant Cell Physiol.

Ruotolo, R., Marchini, G., and Ottonello, S. (2008) Membrane transporters and protein traffic networks differentially affecting metal tolerance: a genomic phenotyping study in yeast. Genome Biol. 9: R67.

Schaaf, G., Honsbein, A., Meda, A.R., Kirchner, S., Wipf, D., and von Wiren, N. (2006) AtIREG2 encodes a tonoplast transport protein involved in iron-dependent nickel detoxification in Arabidopsis thaliana roots. J Biol Chem. 281: 25532-25540.

Seregin, I. V, and Kozhevnikova, A.D. (2006) Physiological role of nickel and its toxic effects on higher plants. Russ J Plant Physiol. 53: 257-277.

Zwiewka, M., Bielach, A., Tamizhselvan, P., Madhavan, S., Ryad, E.E., Tan, S., et al. (2019) Root Adaptation to $\mathrm{H} 2 \mathrm{O} 2-$ Induced Oxidative Stress by ARF-GEF BEN1- and Cytoskeleton-Mediated PIN2 Trafficking. Plant Cell Physiol. 60: 255-273.

\section{Figure legend}

Fig.1 Nickel fate and responses in plant cells. Nickel is essential for the Urease activity. Nickel enter plant cells via metal transporters including IRT1-related proteins. High nickel concentration competes with iron in cells. Nickel also induces an increase of Reactive Oxygen species (ROS) and a reorientation of the microtubule network. At the transcriptomic level high nickel affects the expression of genes responding to iron deficiency, genes involved in cell wall related processes, and genes implicated in nitrate homeostasis. In root cells, the increase of ROS is proposed to regulate the activity of the PIN2 transporter thus affecting the auxin balance and the development of roots. Excess of nickel is stored in the vacuole to limit its cellular toxicity. 


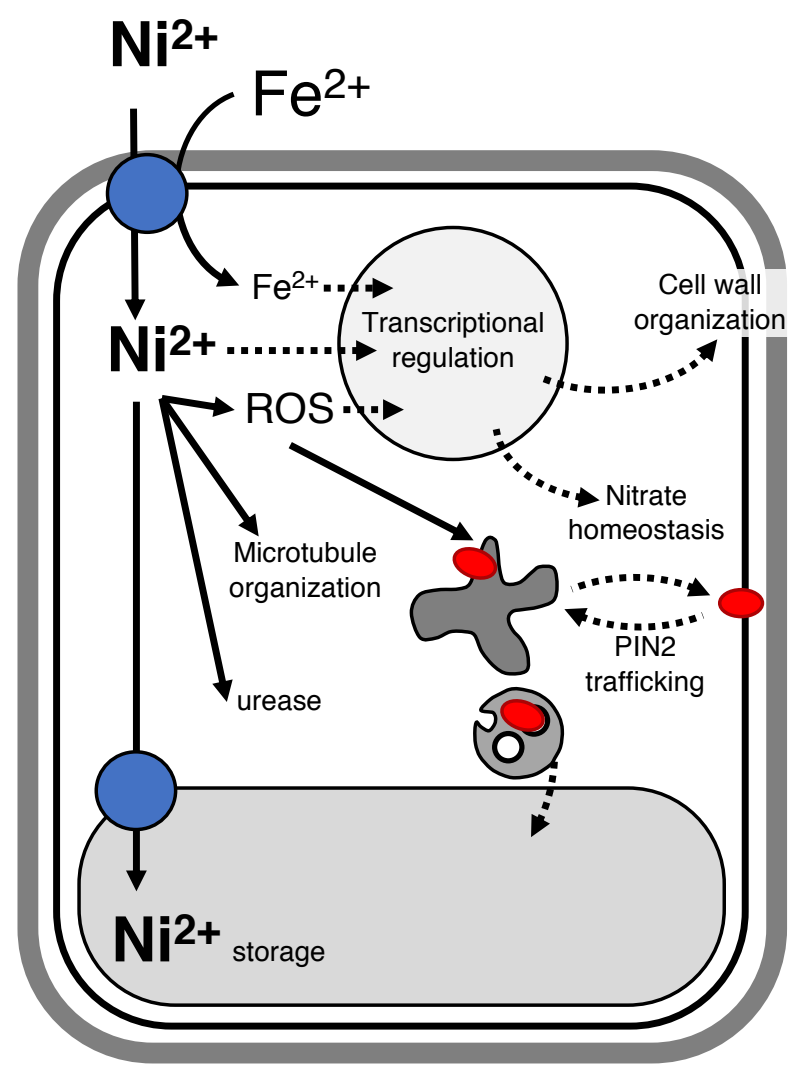

